\title{
Bedside pulse oximeters with a clinical algorithm make economic sense in the intensive care unit
}

\author{
DAVID J LEASA MD FRCPC, JACQUELINE M WALKER RN BScN \\ The Program in Critical Care, Division of Respirology, and University Hospital, \\ The University of Western Ontario, London, Ontario
}

DJ LEASA, JM WALKER. Bedside pulse oximeters with a clinical algorithm make economic sense in the intensive care unit. Can Respir J 1996;3(1):47-51

OBJECTIVE: To determine the effect on arterial blood gas (ABG) and hospital resource use by introducing a strategy of using bedside oximeters with a clinical algorithm, based on the argument that bedside pulse oximeters make economic sense in the intensive care unit (ICU) if safe patient oxygenation can be ensured at a lower cost than that of existing monitoring options.

DESIGN: A before and after design was used to examine the consequences of a pulse oximeter at each bedside in the ICU along with a pulse oximeter clinical algorithm (POCA) describing use for titrating oxygen therapy and for performing ABG analysis.

SETTING: A 19-bed multidisciplinary ICU with a six-bed extended ICU (EICU) available to function as a 'step-down' facility.

PATIENTS: All patients admitted to the ICU/EICU over two 12-month periods were included.

RESULTS: The strategy yielded a 31\% reduction in the mean number of ABGs per patient after POCA (20.0 \pm 26.1 versus $13.8 \pm 16.7$, mean $\pm \mathrm{SD} ; \mathrm{P}<0.001)$ as well as a potential annual cost savings of $\$ 32,831$.

CONCLUSIONS: Bedside oximeters within the ICU, when used with explicit guidelines, reduce $\mathrm{ABG}$ use and result in hospital cost savings.

Key Words: Arterial blood gas use, Clinical algorithms, Cost analysis, Intensive care, Oximetry
D'un point de vue économique, les oxymètres de pouls s'accompagnant d'un algorithme clinique et installés au chevet du malade ont leur raison d'être dans un service de soins intensifs

OBJECTIF : Déterminer l'effet sur les gaz artériels et l'utilisation des ressources hospitalières de l'introduction d'une stratégie visant à utiliser des oxymètres au chevet avec un algorithme clinique, selon l'argument que d'un point de vue économique ces appareils ont leur raison d'être aux soins intensifs si l'oxygénation des patients peut être assurée de manière fiable à un coût inférieur à celui du monitorage actuel.

MODÈLE : On a utilisé un modèle préalable et postérieur pour examiner les conséquences de l'installation d'un oxymètre de pouls, au chevet de chaque patient dans un service de soins intensifs. Cet oxymètre s'accompagnait d'un algorithme clinique décrivant son utilisation pour doser l'oxygénothérapie et pour pratiquer l'analyse des gaz artériels.

CONTEXTE : Un service de soins intensifs multidisciplinaires de 19 lits avec une extension de six lits faisant fonction d'unité de transition.

PATIENTS : Tous les patients admis au service de soins intensifs et à l'unité de transition sur deux périodes de 12 mois.

RÉSULTATS : La stratégie a résulté en une diminution de $31 \%$ (20.0 26.1 comparativement à $13.8 \pm 16.7$, écart type moyen; $\mathrm{P}<0.001)$ du nombre moyen de gaz artériels par patient après l'installation d'un oxymètre de pouls accompagné d'un algorithme clinique. De plus, les économies potentielles annuelles s'élevaient à 32831 dollars.

CONCLUSIONS : Les oxymètres au chevet dans un service de soins intensifs, utilisés selon un mode d'emploi explicite, réduisent l'analyse des gaz artériels et entraînent une diminution des coûts hospitaliers. 
$\mathrm{P}$ ulse oximetry has been extensively adopted in the intensive care unit (ICU) over the past few years in the absence of definitive studies demonstrating efficacy $(1,2)$. This is not unanticipated given the oximeter's ease of use and noninvasiveness, plus the widespread belief that the identification of serious arterial desaturation would be inappropriately delayed by using clinical signs or intermittent arterial blood gas (ABG) analysis. Though observational data from the operating room suggest a decreased incidence and duration of arterial desaturation with fewer adverse consequences $(3,4)$, appropriately designed studies may never be performed within the ICU to answer the question of whether patient outcomes are improved by oximeters. Given the similarities between the two environments, it seems reasonable to assume that the results are applicable to the ICU. Nevertheless, even if it has not been firmly established that oximetry affects patient outcome positively, it has been argued that it is still worthwhile to use routine oximetry in the ICU if it accomplishes the expected tasks at a lower cost (5). For the potential user, it then becomes a question of determining the most economical manner of ensuring adequate oxygenation at the bedside.

Pulse oximetry has two advantages over clinical signs and intermittent $\mathrm{ABG}$ analysis: first, it can act as a warning system for detecting hypoxemia, with the potential to prevent the adverse patient consequences of arterial desaturation; and second, it can be used as an end-point for the titration of in- spired oxygen $\left(\mathrm{FIO}_{2}\right)$ and positive end-expiratory pressure (PEEP), hence serving as a response indicator. With these advantages in mind, we introduced a strategy of using bedside oximeters with a clinical algorithm in our ICU to determine the effect on $\mathrm{ABG}$ and hospital resource use.

\section{PATIENTS AND METHODS}

Clinical setting: The ICU at University Hospital is a 19-bed, multidisciplinary unit with house staff available in the unit $24 \mathrm{~h}$ a day. A dedicated intensive care physician is available at all times and coordinates patient management with other health care professionals. One nurse per patient is the usual staffing practice and a respiratory technologist is always available for ventilator and oxygen therapy management. An extended ICU (EICU) of six beds is available to function as a 'step-down' facility. All hospital patients requiring mechanical ventilation, excluding those in the operating room, are managed in these units. ABG analysis (Pulmonary Function Laboratory), biochemistry and hematology are performed outside the ICU/EICU by technicians, and samples require transport to the laboratories by ancillary staff.

Study design: Clinical activity and $\mathrm{ABG}$, electrolyte and hemoglobin use were recorded over two 12-month periods. From January 1, 1991 to December 31, 1991, five standalone oximeters were shared among the 25 beds, but without a clinical algorithm for expected use. Although ABG analysis was mandatory for all patients every morning it also fre-

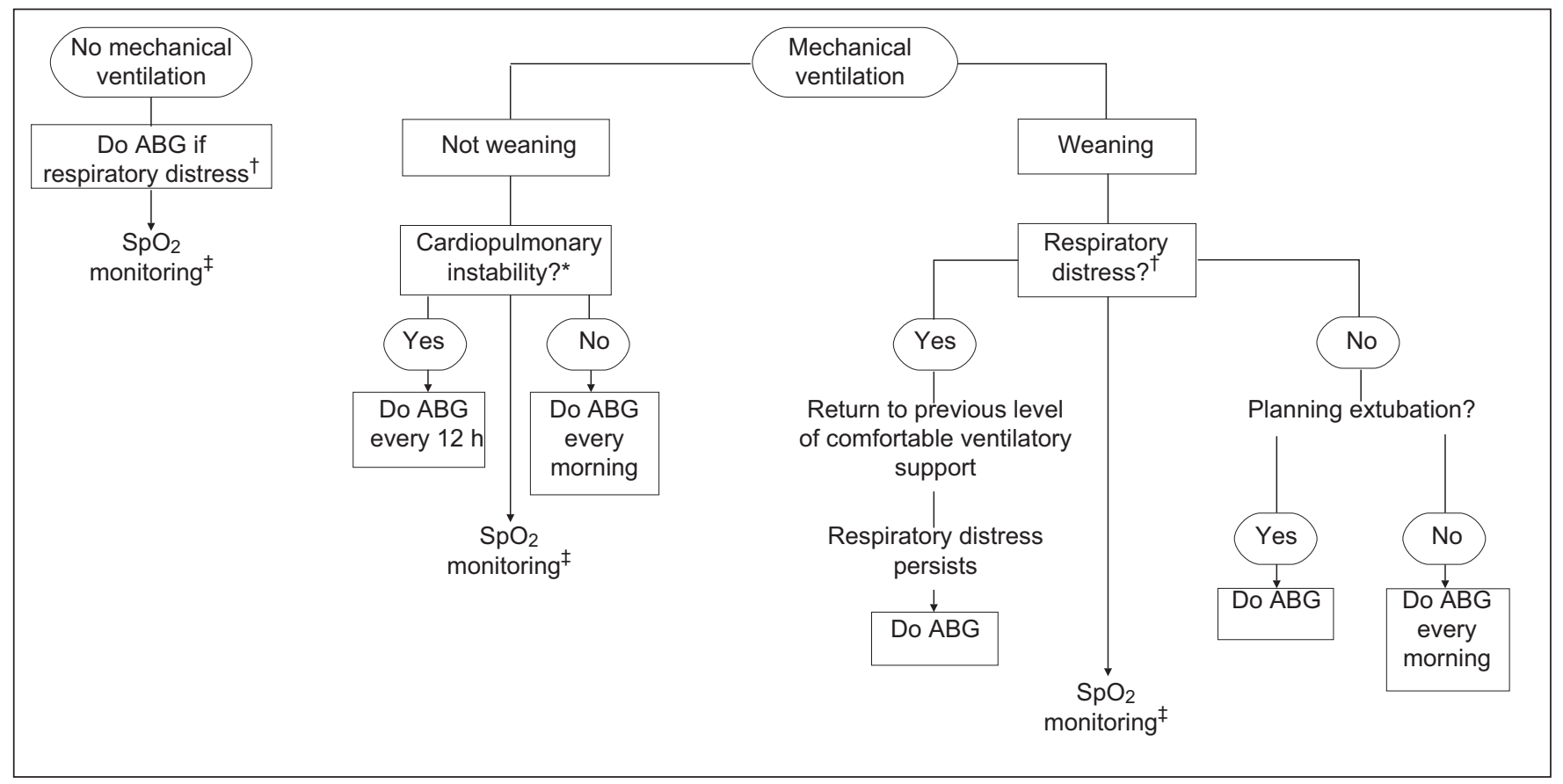

Figure 1) Clinical algorithm describing pulse oximeter use for arterial blood gas $(A B G)$ sampling and for titrating oxygen therapy. *Cardiopulmonary instability is defined as a condition where one or more of the following is present: vasopressor therapy to maintain blood pressure; Positive end-expiratory pressure $>10 \mathrm{~cm} \mathrm{H}_{2} \mathrm{O}$; acidosis with $\mathrm{pH}<7.30$; pharmacological paralysis; or controlled hyperventilation. ${ }^{\dagger} \mathrm{Respira-}$ tory distress is defined as a condition where one of more of the following is present: respiratory rate $>35 \mathrm{breaths} / \mathrm{min}$; diaphoresis; asynchrony of breathing; or inspiratory abdominal paradox. Oximeter saturation $\left(\mathrm{SpO}_{2}\right)$ monitoring is defined as the following set of instructions. The bedside staff may increase or decrease fraction of inspired oxygen $\left(F_{I} O_{2}\right)$ by increments of 0.10 until $\mathrm{SpO} \mathrm{O}_{2} \geq 93 \%$ and $\leq 97 \%$, without the need for $A B G$ sampling. The intensive care unit (ICU) physician may order a different $\mathrm{SpO}_{2}$ 'target' value, should the clinical situation so dictate. The ICU physician must be informed if an $\mathrm{F}_{\mathrm{I}} \mathrm{O}_{2}>0.60$ is required to keep the $\mathrm{SpO}_{2} \geq 93 \%$ 
TABLE 1

\begin{tabular}{|c|c|c|c|}
\hline & $\begin{array}{l}\text { Before } \\
\text { POCA* }\end{array}$ & $\begin{array}{c}\text { After } \\
\text { POCA }^{\dagger}\end{array}$ & $\begin{array}{c}P \\
\text { value }\end{array}$ \\
\hline Duration (months) & 12 & 12 & \\
\hline Number of patients & 1025 & 1106 & \\
\hline Number of admissions & 1105 & 1201 & \\
\hline Age (mean years $\pm \mathrm{SD}$ ) & $58 \pm 15$ & $60 \pm 15$ & $<0.05$ \\
\hline Mechanical ventilation (\%) & 92 & 91 & NS \\
\hline Operative admissions ( $\mathrm{n}, \%)$ & $775(70)$ & $830(69)$ & NS \\
\hline CABG & $408(37)$ & $439(37)$ & \\
\hline Heart valve surgery & $105(10)$ & $113(9)$ & \\
\hline Transplant & $83(8)$ & $79(7)$ & \\
\hline Thoracic/abdominal aneurysm & $50(5)$ & $56(5)$ & \\
\hline Trauma & $9(1)$ & $14(1)$ & \\
\hline Nonoperative admissions (n, \%) & $330(30)$ & $371(31)$ & NS \\
\hline Pneumonia & $42(4)$ & $45(4)$ & \\
\hline $\mathrm{SAH} / \mathrm{ICH} /$ stroke & $30(3)$ & $37(3)$ & \\
\hline Cardiac arrest & $25(2)$ & $27(2)$ & \\
\hline Trauma & $21(2)$ & $22(2)$ & \\
\hline Congestive heart failure & $18(2)$ & $23(2)$ & \\
\hline ICU mortality (\%) & 11.1 & 10.9 & NS \\
\hline
\end{tabular}

CABG Coronary artery bypass graft; ICH Intracranial hemorrhage; ICU Intensive care unit; NS Not significant; POCA Pulse oximetry with clinical algorithm; SAH Subarachnoid hemorrhage. ${ }^{*}$ Before POCA, January 1, 1991 to December 31,$1991 ;{ }^{\dagger}$ After POCA, August 1, 1992 to July 31, 1993

quently followed changes in ventilator or oxygen support. From August 1, 1992 to July 31, 1993, each bedside within the ICU had its own oximeter (Hewlett Packard Component Monitoring System with M1020A oxygen saturation modules, Hewlett Packard, Massachusetts) and the five shared units were used in the six-bed EICU; however, a pulse oximeter clinical algorithm (POCA) describing oximeter use for titrating oxygen therapy and for performing $\mathrm{ABG}$ analysis was included (Figure 1). It was believed that $\mathrm{ABG}$ and not other blood sampling frequencies would be influenced by POCA.

Oximetry accuracy and clinical algorithm development: Oximeter accuracy was assessed before the new strategy was introduced into the usual ICU care. For a one-month period, oximeter saturation $\left(\mathrm{SpO}_{2}\right)$ of the M1020A oxygen saturation modules at the time of ABG sampling was recorded and compared with arterial saturation $\left(\mathrm{SaO}_{2}\right)$, measured using a six-wavelength co-oximeter (OSM3 Hemoximeter, Radiometer, Copenhagen, Denmark). The bias $\left(\mathrm{SpO}_{2}-\mathrm{SaO}_{2}\right) \pm$ precision (SD) of the oximeters was determined to ensure an 'acceptable' lower limit for $\mathrm{SpO}_{2}$ at the bedside (ie, an $\mathrm{SpO}_{2}$ where $97.5 \%$ of the $\mathrm{SaO}_{2}$ values were $90 \%$ or greater). A clinical algorithm describing oximeter use for ABG sampling and for titrating therapy (using this 'target' $\mathrm{SpO}_{2}$ ) was constructed with ICU staff input, then taught and implemented (6). Staff compliance with ABG sampling was evaluated six months following introduction of the guidelines.

Cost analysis: A cost minimization analysis of the new strategy, compared with the existing one, was undertaken from
TABLE 2

Blood sampling frequency before and after POCA introduction

\begin{tabular}{|c|c|c|c|c|}
\hline & $\begin{array}{l}\text { Before } \\
\text { POCA }^{\dagger}\end{array}$ & $\begin{array}{c}\text { After } \\
\text { POCA }^{\ddagger}\end{array}$ & $\begin{array}{c}\text { Absolute } \\
\text { difference } \\
(95 \% \mathrm{Cl})\end{array}$ & $\begin{array}{c}P \\
\text { value }\end{array}$ \\
\hline Patient-days & 6411 & 7192 & & \\
\hline ICU LOS (days)* & $6.4 \pm 14$ & $6.6 \pm 14$ & & NS \\
\hline Ventilator-days & 5205 & 5486 & & \\
\hline $\begin{array}{l}\text { Ventilator LOS } \\
\text { (days)* }^{*}\end{array}$ & $5.2 \pm 14$ & $5.1 \pm 12$ & & NS \\
\hline ABG samples & 20,166 & 14,984 & & \\
\hline ABG/patient* & $20.0 \pm 26.1$ & $13.8 \pm 16.7$ & $\begin{array}{c}-6.2 \\
(-4.3 \text { to }-8.1)\end{array}$ & $\begin{array}{c}<0.00 \\
1\end{array}$ \\
\hline $\begin{array}{c}\text { Electrolyte } \\
\text { samples }\end{array}$ & 12,481 & 11,780 & & \\
\hline $\begin{array}{l}\text { Electrolyte } \\
\text { samples/patient* }\end{array}$ & $12.4 \pm 18.7$ & $10.9 \pm 14.0$ & $\begin{array}{c}-1.5 \\
(-0.1 \text { to }-2.9)\end{array}$ & NS \\
\hline $\begin{array}{l}\text { Hemoglobin } \\
\text { samples }\end{array}$ & 11,100 & 10,648 & & \\
\hline $\begin{array}{l}\text { Hemoglobin } \\
\text { samples/patient* }\end{array}$ & $11.0 \pm 16.2$ & $9.8 \pm 12.6$ & $\begin{array}{c}-1.2 \\
(0.1 \text { to }-2.4)\end{array}$ & NS \\
\hline
\end{tabular}

ABG Arterial blood gas samples; ICU Intensive care unit; LOS Length of stay; POCA Pulse oximetry with clinical algorithm. *Mean $\pm S D$; ${ }^{\dagger}$ Before POCA January 1, 1991 to December 31, 1991; ${ }^{\ddagger}$ After POCA August 1, 1992 to July 31, 1993; Absolute difference $(95 \% \mathrm{Cl})$ before-after with $95 \% \mathrm{Cl}$ for the absolute difference

the viewpoint of the hospital (5). The capital cost of acquiring the pulse oximeter modules, above the cost of the bedside monitoring system, was treated as a straight-line depreciation cost per year over a period of five years, which was judged to be a conservative estimate of the clinical life of the oximeters. The annual operating cost of the oximeters was determined during the 12-month study and included actual expenses to replace damaged finger probes and cables. The annual cost reduction of the strategy was calculated using the 'controllable' cost of an ABG sample to the hospital, the expected number of ICU patients per year and the actual ABG reduction rate per patient. The controllable cost of an $\mathrm{ABG}$ sample to the hospital was $\$ 6.55$ (April 1993). The components of this cost included direct labour worked (\$3.68) and not-worked hours (\$0.77), employee benefits $(\$ 0.64)$, direct materials (\$0.26), direct overhead (\$0.42) and direct equipment depreciation $(\$ 0.77)$.

Statistical methods: Unpaired $t$ tests (two-sided) were used to compare quantitative variables of the before and after groups. A $\chi^{2}$ test was used for noncontinuous variables. The Bonferroni correction for multiple comparisons was applied. $\mathrm{P}<0.05$ was taken as significant.

\section{RESULTS}

Oximeter accuracy and clinical algorithm development: Three-hundred and forty-eight $\mathrm{SpO}_{2} / \mathrm{SaO}_{2}$ consecutive data sets from a one-month period were assessed to define oximetry accuracy. The bias $\pm \mathrm{SD}$ was $-0.08 \pm 1.28 \%$ for a $\mathrm{SaO}_{2}$ range of 89 to $100 \%$. The $\mathrm{SaO}_{2} 95 \% \mathrm{CI}$ for a $\mathrm{SpO}_{2}$ reading of 
TABLE 3

Financial impact of acquiring POCA

\begin{tabular}{|c|c|c|c|}
\hline & Quantity & Cost/item & (Cost) or Savings \\
\hline \multicolumn{4}{|l|}{ A. Pulse oximeter capital costs per year } \\
\hline Initial outlay for pulse oximeters & 19 & $\$ 3,484$ & $(\$ 66,192)$ \\
\hline Depreciation cost per year (over 5 years)* & & & $(\$ 13,239)(A)$ \\
\hline \multicolumn{4}{|l|}{ B. Pulse oximeter operating costs per year } \\
\hline Extra cables & 2 & $\$ 146$ & $(\$ 292)$ \\
\hline Extra finger probes & 16 & $\$ 214$ & $(\$ 3,424)$ \\
\hline Operating costs per year & & & $(\$ 3,716)(\mathrm{B})$ \\
\hline \multicolumn{4}{|c|}{ C. Estimated cost reduction per year in $A B G$ analysis using POCA } \\
\hline Hospital ABG analysis cost & & $\$ 6.55$ & \\
\hline$A B G$ reduction per patient with $P O C A$ & 6.2 & & \\
\hline Estimated number of patients per year & 1100 & & \\
\hline Estimated cost reduction per year in $A B G$ & & & $\$ 44,671(\mathrm{C})$ \\
\hline \multicolumn{4}{|c|}{ D. Estimated cost reduction per year in supplies using POCA } \\
\hline ABG kit & & $\$ 0.55$ & \\
\hline Dead space syringe & & $\$ 0.05$ & \\
\hline Pair of gloves & & $\$ 0.10$ & \\
\hline Order form & & $\$ 0.05$ & \\
\hline$A B G$ reduction per patient with $P O C A$ & 6.2 & & \\
\hline Estimated number of patients per year & 1100 & & \\
\hline Estimated cost reduction per year in supplies & & & $\$ 5,115(\mathrm{D})$ \\
\hline \multirow[t]{3}{*}{ Estimated savings per year using POCA } & \multicolumn{3}{|l|}{$=(C+D)-(A+B)$} \\
\hline & \multicolumn{3}{|c|}{$=(\$ 44,671+\$ 5,115)-(\$ 13,239+\$ 3,716)$} \\
\hline & \multicolumn{3}{|l|}{$=\$ 32,831$} \\
\hline
\end{tabular}

ABG Arterial blood gas; POCA Pulse oximetry with clinical algorithm; *Treated as a straight-line depreciation cost over a period of five years

93\% was determined to be 90.4 to $95.4 \%$. In the clinical algorithm construction a target $\mathrm{SpO}_{2}$ reading $93 \%$ or greater was used to ensure 'safe' arterial oxygenation (Figure 1).

Demographic characteristics before and after POCA: The demographic characteristics of the patients studied during the two 12-month periods are shown in Tables 1 and 2. Patient characteristics were similar except that average patient age was higher after POCA introduction ( $58 \pm 15$ versus $60 \pm 15$ years, mean $\pm \mathrm{SD}, \mathrm{P}<0.05$ ).

Blood sampling frequencies before and after POCA: Both the mean number of ABGs per patient (20.0 \pm 26.1 versus $13.8 \pm 16.7, \mathrm{P}<0.001)$ and the mean number of $A B G s$ per patient-day $(4.70 \pm 2.14$ versus $3.14 \pm 1.75, \mathrm{P}<0.001)$ were less after the introduction of POCA (Table 2). The mean number of serum electrolytes per patient (12.4 \pm 18.7 versus $10.9 \pm 14.0, \mathrm{P}=0.40$ ) and the mean number of hemoglobin determinations per patient $(11.0 \pm 16.2$ versus $9.8 \pm 12.6, \mathrm{P}=0.60)$ were unchanged after the introduction of POCA.

Cost analysis: The capital cost of acquiring the oximeter modules was $\$ 66,192$ but was treated as a straight-line depreciation cost of $\$ 13,239$ (A) per year, over a period of five years (Table 3 ). An annual operating cost of \$3,716 (B) was required to replace damaged finger probes and cables. Given 1100 ICU patients per year and a 6.2 ABG reduction per patient following POCA, an annual cost reduction in ABG testing of $\$ 44,671$ (C) was possible. An additional annual cost reduction of $\$ 5,115$ (D) was possible as a consequence of less use of gloves, syringes and blood gas kits. Hence, the total cost savings to the hospital for the 12-month period after
POCA implementation was \$32,831 ([C+D] - [A+B]). A greater cost savings was considered possible as an audit six months after POCA implementation revealed that the guidelines were correctly followed for ABG sampling only $65 \%$ of the time.

\section{DISCUSSION}

We found a $31 \%$ reduction in ABG use in our ICU following the introduction of bedside pulse oximeters when used with explicit guidelines. At the same time, there were no apparent differences in patient outcome, including mortality and duration of ventilatory support and ICU stay. With this strategy the hospital experienced a potential annual savings of $\$ 32,831$. In fact, an actual savings for the hospital occurred as 1.5 fulltime equivalent positions were eliminated within the blood gas laboratory over the past three years, in part due to the reduced ABG workload (in that the ICU provided approximately $50 \%$ of the hospital ABG workload). Whether such savings would occur in other hospitals is uncertain and would likely be influenced by the characteristics of the patient population, the monitoring protocols in place, compliance with the guidelines, and whether ABG analysis is external or internal to the ICU.

Our findings agree with those of a recent randomized trial of continuous pulse oximetry in 35 patients after elective cardiac surgery (7). In that small study the ICU staff were instructed to obtain a mandatory ABG analysis each morning but to use the pulse oximetry data in lieu of $A B G$ analysis whenever possible. The mean number of $\mathrm{ABG}$ analyses per 
patient $( \pm$ SD) was comparable with our results $(23.1 \pm 8.8$ versus $20.0 \pm 26.1$ without the oximetry strategy and $12.4 \pm 7.5$ versus $13.8 \pm 16.7$ with the oximetry strategy, respectively). Our results, however, can be generalized to a multidisciplinary ICU and include an assessment of the economic benefits of the strategy. In contrast, two other recent studies did not demonstrate a change in $\mathrm{ABG}$ use following the introduction of oximeters within the ICU $(8,9)$. One possible explanation for this discordance is that explicit instructions for use of the oximeter and for ABG sampling were not given to the ICU staff in those studies. Clinical algorithms designed to give rational indications for ABG analysis $(10,11)$, without compromising patient outcome, are necessary to make oximeters economically attractive within the ICU.

This study is limited by the before-after design. Although the patients studied in the two time periods were similar, we cannot be certain that other unmeasured confounders were

\section{REFERENCES}

1. Technology Subcommittee of the Working Group on Critical Care, Ontario Ministry of Health. Noninvasive blood gas monitoring: a review for use in the adult critical care unit. Can Med Assoc J 1992;146:703-12.

2. Barker SJ. Role of pulse oximetry in the ICU. Chest 1993;104:330-1.

3. Cote CJ, Goldstein EA, Cote MA, Hoaglin DC, Ryan JF. A single-blind study of pulse oximetry in children. Anesthesiology 1988;68:184-8

4. Cote CJ, Rolf N, Liu LM, et al. A single-blind study of combined pulse oximetry and capnography in children. Anesthesiology 1991;74:980-7

5. The Technology Assessment Task Force of the Society of Critical Care Medicine. A model for technology assessment applied to pulse oximetry. Crit Care Med 1993;21:615-24.

6. Jubran A, Tobin MJ. Reliability of pulse oximetry in titrating present. Bias may also result from unappreciated changes in the ICU environment and from interventions other than oximetry being responsible for the $\mathrm{ABG}$ reduction. The fact that electrolyte and hemoglobin sampling frequency did not significantly change supports our argument that the intervention and not other factors was responsible for the reduction in $\mathrm{ABG}$ analysis.

In conclusion, use of oximeters within our ICU, in combination with explicit guidelines, was associated with a significant reduction in $\mathrm{ABG}$ analysis and resulted in hospital savings.

ACKNOWLEDGEMENTS: We thank Jane Loughlin, Marjorie Johnson and Anna Gallie for data retrieval, Randy Welch and Ravinder Singh for critical review of the cost analysis and Drs Gord Doig and Jeff Mahon for manuscript suggestions.

supplemental oxygen therapy in ventilator-dependent patients. Chest 1990;97:1420-5.

7. Bierman MI, Stein KL, Snyder JV. Pulse oximetry in the postoperative care of cardiac surgical patients. A randomized controlled trial. Chest 1992;102:1367-70

8. Inman KJ, Sibbald WJ, Rutledge FS, Speechley M, Martin CM, Clark BJ. Does implementing pulse oximetry in a critical care unit result in substantial arterial blood gas savings? Chest 1992;104:542-6.

9. Solsona JF, Marrugat J, Vazquez A, Masdeu G, Alvarez F, Nolla J. Effect of pulse oximetry on clinical practice in the intensive care unit. Lancet 1993;342:311-2.

10. Roberts D, Ostryzniuk P, Loewen E, et al. Control of blood gas measurements in intensive-care units. Lancet 1991;337:1580-2.

11. Grimshaw JM, Russell IT. Effect of clinical guidelines on medical practice: a systematic review of rigorous evaluations. Lancet $1993 ; 342: 1317-22$. 


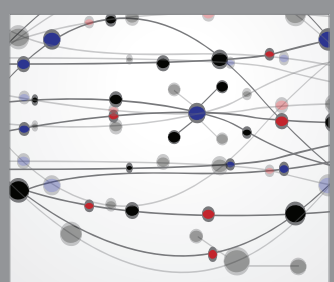

The Scientific World Journal
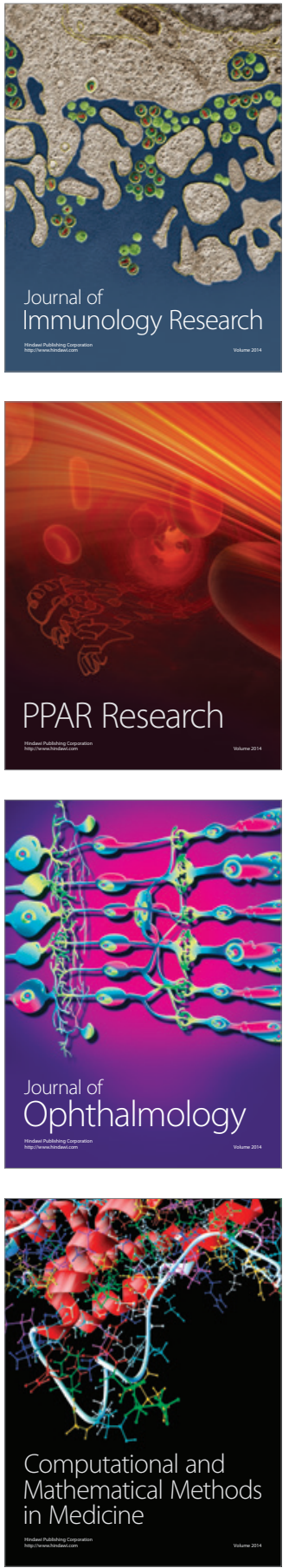

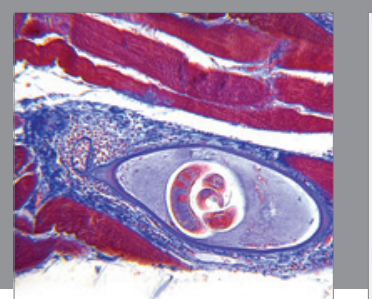

Gastroenterology Research and Practice

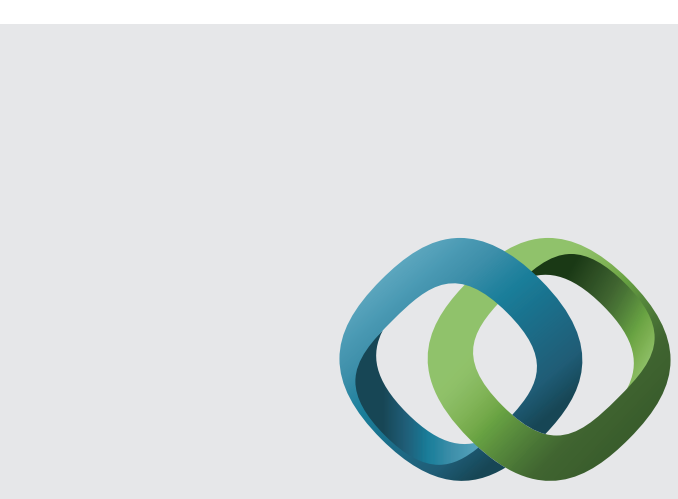

\section{Hindawi}

Submit your manuscripts at

http://www.hindawi.com
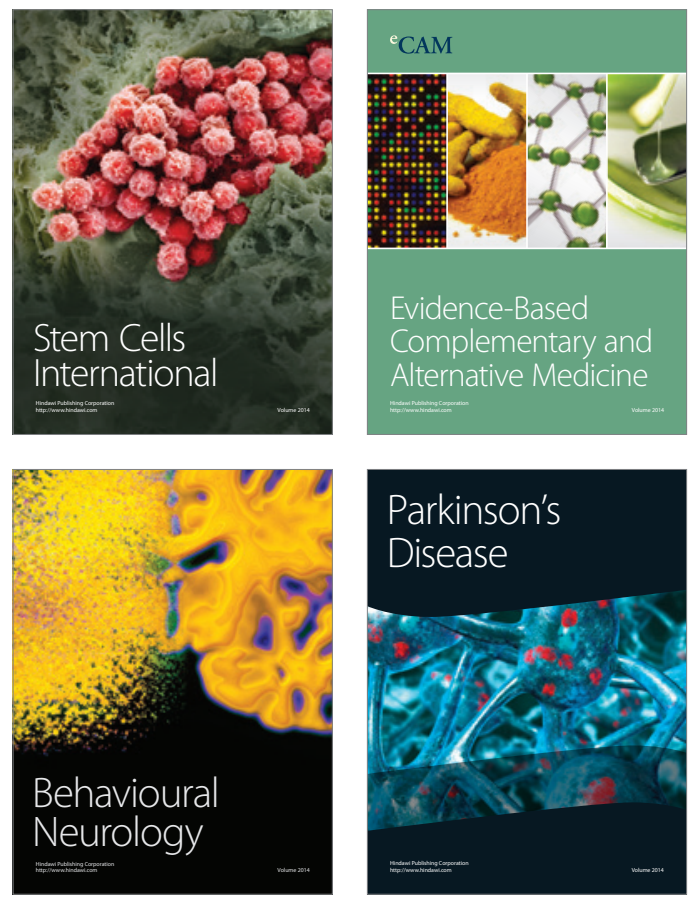
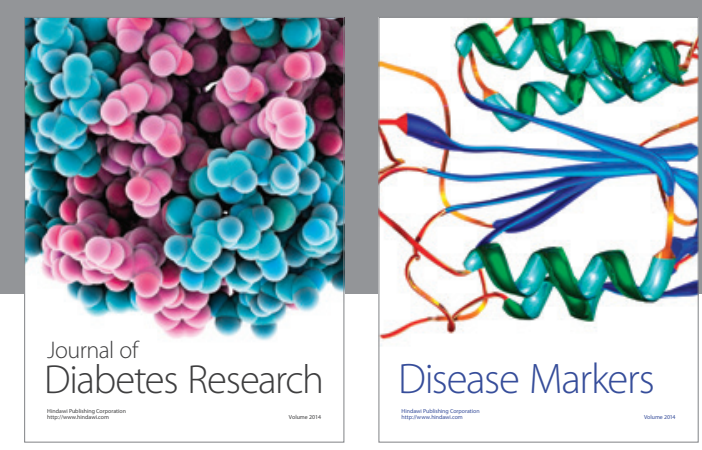

Disease Markers
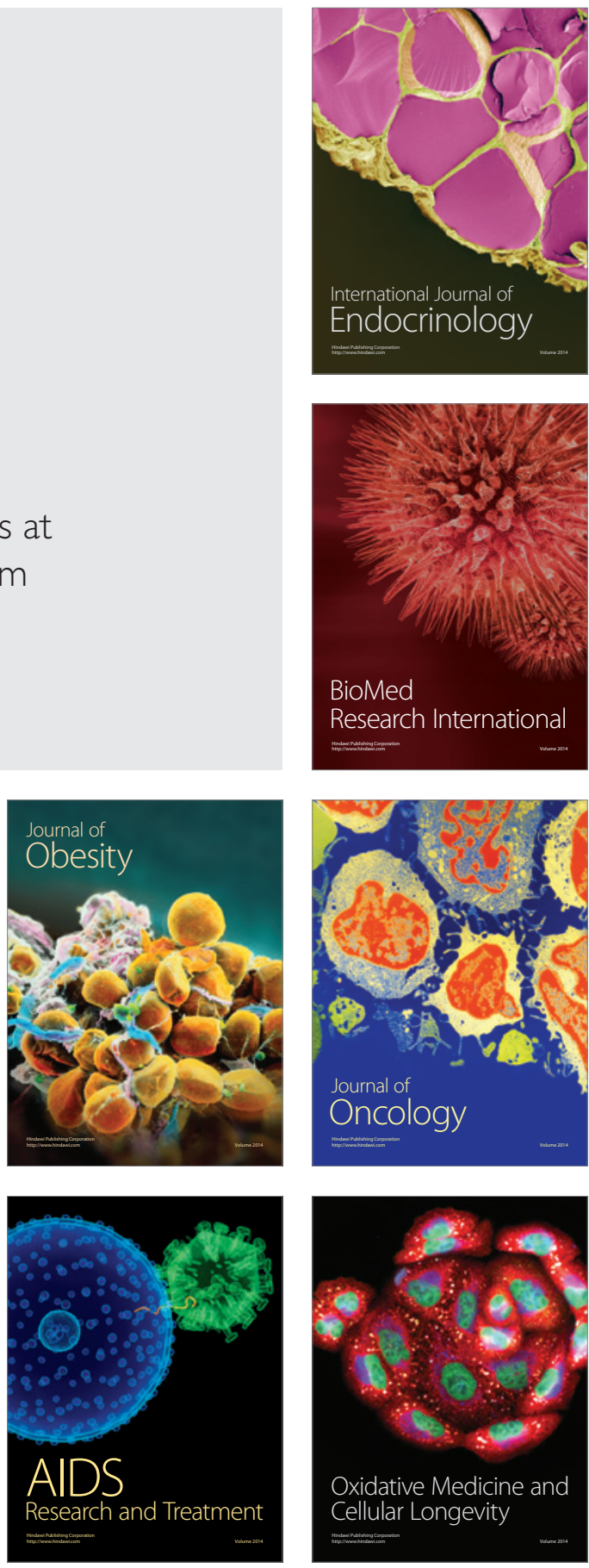